\title{
Molecular epidemiology and viral load of HCV in different regions of Punjab, Pakistan
}

\author{
Suliman Qadir Afridi ${ }^{{ }^{*}+}$, Muhammad Muddassir Ali ${ }^{2 \dagger}$, Furqan Awan ${ }^{3+}$, Muhammad Nauman Zahid ${ }^{1}$, Irfan Qadir Afridi ${ }^{4}$, \\ Sara Qadir Afridi ${ }^{4}$ and Tahir Yaqub ${ }^{1}$
}

\begin{abstract}
Background: Hepatitis $\mathrm{C}$ virus (HCV) is highly infectious pathogen which is responsible for causing Hepatitis around 200 million individuals worldwide. In Pakistan, 4.7\% of HCV prevalence has been reported and HCV genotype 3a has been found to be the major source of infection in Pakistan but still there is lack of information on distribution of HCV genotypes and viral load in various geographical regions of Pakistan. Therefore, current study was designed to determine distribution of HCV genotypes as well viral load in different areas of Punjab province of Pakistan.
\end{abstract}

Findings: A total of 995 serum samples were taken from those individuals in which antibodies against HCV were detected through ELISA, from different regions of Punjab i.e. Lahore 317(31.85\%), Faisalabad 70(7.03\%), Gujranwala 129(12.96\%), Gujrat 106(10.65\%), Sialkot 94(9.44\%), Sargodha 60(6.03\%), Mandibaha-ud-din 135(13.56\%), Jhang 86 (8.64\%). Qualitative PCR was performed to determine viral load and genotyping was performed using Nested PCR. Chi-square test was used to determine the age and sex-wise prevalence of HCV. Out of 995 samples, 888 samples were found positive for HCV RNA. In all regions, genotype 3a showed highest prevalence (82.81\%) followed by genotype 1 (3.41\%), mixed genotypes (2.41\%), genotype $2(0.50 \%)$, genotype $5(0.1 \%)$ and unclassified genotypes (10.75\%). Viral load in $29.5 \%$ patients infected with genotype 3a was less than $600,000 \mathrm{IU} / \mathrm{mL}$, while it was between $600,000-800,000 \mathrm{IU} / \mathrm{mL}$ in $27.9 \%$ patients and $25.22 \%$ patients had more than $800,000 \mathrm{IU} / \mathrm{mL}$ viral load.

Conclusion: HCV genotype $3 \mathrm{a}$ is the most prevalent genotype in various regions of Punjab. Viral load of HCV patients in these different regions of Punjab are reported for the first time. Moreover, based upon these results the Patients having viral load below $800,000 \mathrm{IU} / \mathrm{mL}$ would be expected to show better response of anti-HCV therapy.

Keywords: Hepatitis C virus, Genotype 3a, Pakistan, Viral load

\section{Findings \\ Background}

Hepatitis $\mathrm{C}$ virus (HCV) is a globally distributed human pathogen that has affected around 200 million individuals. It is a principle cause of chronic liver disorders including liver cirrhosis, liver fibrosis and hepatocellular carcinoma. HCV is a positive-sense single-stranded RNA virus belonging to genus Hepacivirus, the member of Flaviviridae family, with characteristic of genetic heterogeneity [1]. HCV is an enveloped virus that contains small genome of about 9,600 nucleotides [2]. Due to genetic variability, there are 6 extensively identified genotypes and each genotype has difference of $30 \%-35 \%$ in its nucleotide site sequence from others $[1,3]$.

\footnotetext{
* Correspondence: suliman_afridi16@yahoo.com

${ }^{\dagger}$ Equal contributors

${ }^{1}$ Quality Operations Laboratory, UVAS, Lahore 54000, Pakistan

Full list of author information is available at the end of the article
}

Each genotype contains several subtypes having more than $75 \%$ nucleotide sequence similarity among them [4]. In comparison, more than $95 \%$ of the virions infecting one patient are similar [5]. HCV genotype/subtype identification is crucial for clinicians when it comes to choosing a therapy because these genotypes have been reported to exhibit different responses to prescribed anti-viral therapies and require varying duration and doses of therapy [6]. The transmission of $\mathrm{HCV}$ is on average six times more likely than HIV after a percutaneous exposure [7]. The distribution of virus is worldwide but some strains are particularly detected in specific geographical regions. HCV genotypes $1 \mathrm{a}, 1 \mathrm{~b}$, and $3 \mathrm{a}$ are prevalent "epidemic" strains all over the world [7]. During $20^{\text {th }}$ century above mentioned strains spread quickly, probably through infected blood-products and use of injectable drugs, and possess comparatively less genetic variations. On the other hand, other $\mathrm{HCV}$ strains 
Table 1 HCV prevalence in different regions of Punjab province

\begin{tabular}{|c|c|c|c|c|c|c|c|c|c|}
\hline \multirow[t]{2}{*}{ Genotype } & \multirow[t]{2}{*}{ Sub-type } & \multicolumn{8}{|c|}{ Districts* } \\
\hline & & Lahore & Faisalabad & Gujranwala & Gujrat & Sialkot & Sargodha & Mandi Baha-ud-Din & Jhang \\
\hline \multirow[t]{2}{*}{1} & $1 a$ & $9^{*}(2.83 \%)^{\#}$ & $1(1.42 \%)$ & $4(3.10 \%)$ & $2(1.88 \%)$ & $1(1.06 \%)$ & $2(3.33 \%)$ & $5(3.70 \%)$ & $2(2.32 \%)$ \\
\hline & $1 b$ & $2(0.63 \%)$ & $1(1.42 \%)$ & $1(0.77 \%)$ & 0 & $1(1.06 \%)$ & $1(1.66 \%)$ & $1(0.74 \%)$ & $1(1.16 \%)$ \\
\hline \multirow[t]{2}{*}{2} & $2 a$ & 0 & $1(1.42 \%)$ & 0 & 0 & 0 & $1(1.66 \%)$ & 0 & $1(1.16 \%)$ \\
\hline & $2 b$ & 0 & $1(1.42 \%)$ & $1(0.77 \%)$ & 0 & 0 & 0 & 0 & 0 \\
\hline \multirow[t]{2}{*}{3} & $3 a$ & $240(75.70 \%)$ & 60(85.71\%) & $107(82.94 \%)$ & $98(92.45 \%)$ & $76(80.85 \%)$ & $46(76.66 \%)$ & $119(88.14 \%)$ & 76(88.37\%) \\
\hline & $3 b$ & 0 & 0 & $1(0.77 \%)$ & 0 & 0 & 0 & 0 & $1(1.16 \%)$ \\
\hline 5 & $5 a$ & 0 & 0 & 0 & 0 & $1(1.06 \%)$ & 0 & 0 & 0 \\
\hline Mixed & & $4(1.26 \%)$ & 0 & $6(4.65 \%)$ & $3(2.83 \%)$ & $2(2.12 \%)$ & $3(5 \%)$ & $4(2.96 \%)$ & $2(2.32 \%)$ \\
\hline Not detected & & $62(19.55 \%)$ & $6(8.57 \%)$ & $9(6.97 \%)$ & $3(2.83 \%)$ & $11(11.70 \%)$ & $7(11.66 \%)$ & $6(4.44 \%)$ & $3(3.48 \%)$ \\
\hline Total & & $317(31.85 \%)$ & $70(7.03 \%)$ & 129(12.96\%) & $106(10.65 \%)$ & $92(9.24 \%)$ & $60(6.03 \%)$ & 135(13.56\%) & $86(8.64 \%)$ \\
\hline
\end{tabular}

*Number of samples belonging to respective sub-type.

\#Percentage contributed by samples in the district. 
have high levels of genetic variation but are confined to specific geographical areas [8]. Genotypes 1,2 and 4 are confined to certain regions of Africa and the Middle East, whereas genotypes 3 and 6 , divergent endemic strains, are detected in numerous localities of Southeast Asia [9]. The present study was designed to find different genotypes and viral load of $\mathrm{HCV}$ in different districts of Punjab province of Pakistan.

\section{Methods}

A total of 995 blood samples were collected from those individuals in which antibodies against $\mathrm{HCV}$ were detected through ELISA, to find out their viral load and genotyping situated in different districts/ towns of Punjab, Pakistan. In order to fulfill the legal and ethical requirements, this study got approval by Ethical Committee Bacteriologist to Government of Punjab health department (No. 1029/ Bact.). Written consent was taken to record the age, district, and phone and complete address of the patients. Each blood sample, subjected to get serum, was centrifuged at 3000 RPM for $5 \mathrm{~min}$. Serum obtained were labeled and stored at $-20^{\circ} \mathrm{C}$ till extractions begin.

Extraction of RNA was done using Qiagen kit (Invitrogen, Corp., California; USA). The cDNA of 5'NCR was synthesized using 100 units of Moloney Murine Leukemia Virus (MMLV) reverse transcriptase enzyme (RTEs) (Invitrogen, Corp., California USA) with $5 \mathrm{pM}$ of outer antisense primer. HCV RNA was quantified as the protocol described by Ali et al., 2011 [10]. Two rounds of PCR amplifications were done (first round PCR and Nested PCR) with two units of Taq DNA polymerase enzyme (Invitrogen, Corp., California USA) in a volume of $20 \mu \mathrm{l}$ reaction mix. Different allele-specific primers were used for the detection of HCV genotypes [10]. Chi-square statistics using SPSS version 16.0 (IBM Corporation 2008) was used to analyse the genotype prevalence and distribution among genders and all age groups. $\mathrm{P}$ value $<0.05$ was considered significant.

\section{Results}

Different HCV prevalent genotypes and viral load between both genders in different geographical regions of Punjab province is shown in Table 1 and Table 2. Of 995 samples, 511 (51\%) samples from males and 484(49\%) from females were declared as HCV positive that showed nearly equal representation between both genders. Among these 995 samples, 888 (89.25\%) samples were detected on the basis of specific PCR fragment while 107 (10.75\%) samples remained unable to demonstrate a specific genotypic band. Genotype 3(82.81\%) was highest in both genders followed by genotype 1 (3.41\%), mixed genotypes (2.41\%), genotype $2(0.50 \%)$, genotype $5(0.1 \%)$ and unclassified genotypes (10.75\%), (Figure 1). Among the sub-genotypes, the most detected sub-genotype in males was 3a (80.62\%)
Table 2 HCV viral load in patients from different genders of various regions of Punjab

\begin{tabular}{|c|c|c|c|c|}
\hline \multirow{2}{*}{$\begin{array}{l}\text { Genotype/ } \\
\text { subtype }\end{array}$} & \multicolumn{3}{|c|}{ Viral load } & \multirow{2}{*}{$\begin{array}{c}P \\
\text { value }^{* *}\end{array}$} \\
\hline & $<600,000$ & $600,000-800,000$ & $>800,000$ & \\
\hline Genotype 3 & $294^{*}$ & 278 & 252 & 0.067 \\
\hline Other genotypes & 71 & 42 & 58 & \\
\hline Male & 199 & 159 & 153 & 0.314 \\
\hline Female & 166 & 161 & 157 & \\
\hline \multicolumn{5}{|c|}{ Lahore } \\
\hline Genotype 3 & 79 & 87 & 74 & 0.112 \\
\hline Other genotypes & 24 & 20 & 33 & \\
\hline \multicolumn{5}{|c|}{ Faisalabad } \\
\hline Genotype 3 & 24 & 19 & 17 & 0.260 \\
\hline Other & 4 & 1 & 5 & \\
\hline \multicolumn{5}{|c|}{ Gujranwala } \\
\hline Genotype 3 & 40 & 31 & 37 & 0.932 \\
\hline Other & 7 & 6 & 8 & \\
\hline \multicolumn{5}{|c|}{ Gujrat } \\
\hline Genotype 3 & 31 & 41 & 26 & 0.527 \\
\hline Other & 4 & 2 & 2 & \\
\hline \multicolumn{5}{|c|}{ Sargodha } \\
\hline Genotype 3 & 13 & 18 & 15 & 0.397 \\
\hline Other genotypes & 4 & 3 & 7 & \\
\hline \multicolumn{5}{|c|}{ Silakot } \\
\hline Genotype 3 & 31 & 23 & 22 & 0.915 \\
\hline Other & 7 & 4 & 5 & \\
\hline \multicolumn{5}{|c|}{ Jhang } \\
\hline Genotype 3 & 30 & 25 & 22 & 0.821 \\
\hline Other & 4 & 2 & 3 & \\
\hline \multicolumn{5}{|c|}{ Mandi Baha ud Din } \\
\hline Genotype 3 & 53 & 36 & 30 & 0.278 \\
\hline Other & 10 & 2 & 4 & \\
\hline
\end{tabular}

*Number of samples belonging to respective sub-type and under respective viral load.

${ }^{* *}$ Chi Square statistics used to analyse both genotypes and viral loads.

followed by $1 \mathrm{a}$ subtype $(3.13 \%)$ and $1 \mathrm{~b}$ subtype $(0.98 \%)$. Other less frequent subtypes were $2 \mathrm{a}(0.39 \%), 3 \mathrm{~b}(0.39 \%)$, $2 \mathrm{~b}(0.19 \%)$ and $5 \mathrm{a}(0.19 \%)$. In females, most frequent subgenotypes were $3 \mathrm{a}(84.7 \%), 1 \mathrm{a}(2.06 \%), 1 \mathrm{~b}(0.61 \%), 2 \mathrm{a}$ $(0.20 \%)$ and $2 \mathrm{~b}(0.20 \%)$. On the other hand sub-genotypes like $3 \mathrm{~b}$ and $5 \mathrm{a}$ were absent in females (Figure 1 ).

On basis of age, different groups of genotyped samples were formed such as $10-20$ years, $21-30$ years, 3140 years, $41-50$ years, $51-60$ years and above 60 years. The overall percentage of positive $\mathrm{HCV}$ samples in all age groups was higher in males as compare to females except in the age group $41-50$ years (Figure 2). The distribution of genotypes in all age group categories was also observed. Genotype 3a was highest in all age groups (82.61\%) followed by genotypes 1a (2.61\%), 1b (0.80\%), 2a 


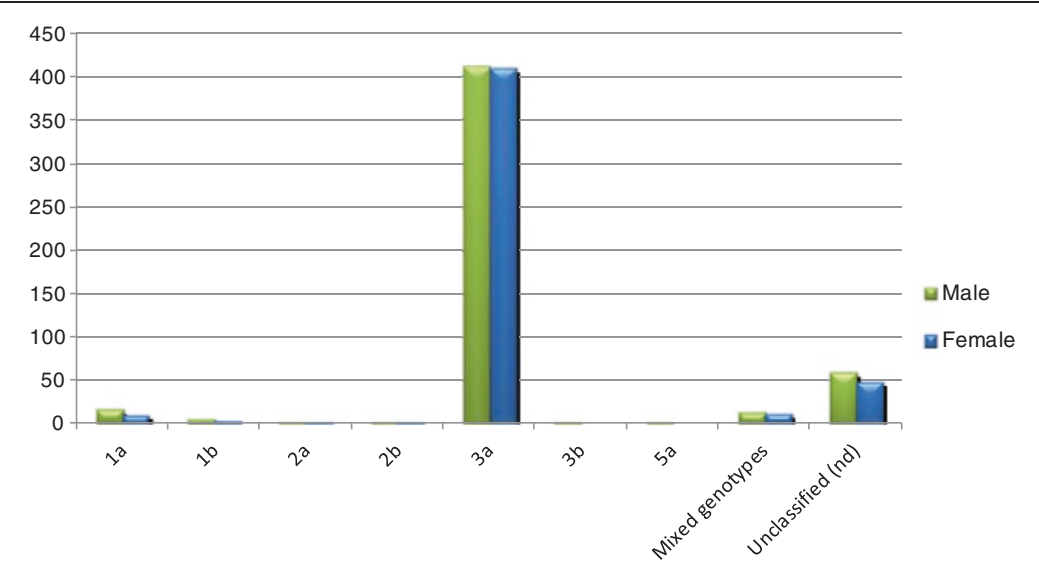

Figure 1 Prevalence of HCV genotypes in different genders.

(0.30\%), 2b (0.20\%), 3b (0.20\%), 5a (0.10\%) and mixed genotypes (2.41\%).

Among the total $\mathrm{HCV}$ positive samples, 317(31.85\%) were belonged to Lahore. Among these, 9(2.83\%) were genotype 1a, 2(0.63\%) were genotype $1 \mathrm{~b}, 240(75.70 \%)$ were genotype 3a whereas 62(19.55\%) were un-typeable and genotype $4(1.26 \%)$ was with mixed genotypes. The HCV positive patients of Faisalabad were $70(7.03 \%)$. Among these, $1(1.42 \%)$ belonged to $1 \mathrm{a}, 1(1.42 \%)$ was $1 \mathrm{~b}, 1(1.42 \%)$ was $2 \mathrm{a}, 1(1.42 \%)$ was $2 \mathrm{~b}, 60(85.71 \%)$ were $3 \mathrm{a}$ and $6(8.57 \%)$ were un-typeable genotypes. Among the total of 129 (12.96\%) samples from Gujranwala, 4(3.10\%) were 1a, 1 $(0.77 \%)$ was $1 \mathrm{~b}, 1(0.77 \%)$ belonged to $2 \mathrm{~b}, 107(82.94 \%)$ were $3 a, 1(0.77 \%)$ was $3 b, 9(6.97 \%)$ were untypeable genotypes and 6(4.65\%) were with mixed genotypes (Table 1).

Prevalence of HCV genotypes among 106(10.65\%) positive patients of Gujrat was $2(1.88 \%)$ patients were with 1a, 98(92.45\%) were with 3a, 3(2.83\%) were with mixed infection and $3(2.83 \%)$ were with unclassified HCV band. Total 94(9.44\%) patients were genotyped from Sialkot in which $1(1.06 \%)$ was $1 \mathrm{a}, 1(1.06 \%)$ were $1 \mathrm{~b}, 1(1.06 \%)$ was $2 \mathrm{a}, 76$ $(80.85 \%)$ were $3 \mathrm{a}, 1(1.06 \%)$ was $3 \mathrm{~b}, 1(1.06 \%)$ was $5 \mathrm{a}$ genotype, 2(2.12\%) were mixed genotypes and 11(11.70\%) were unclassified genotypes. Genotyped samples $\mathrm{HCV}$

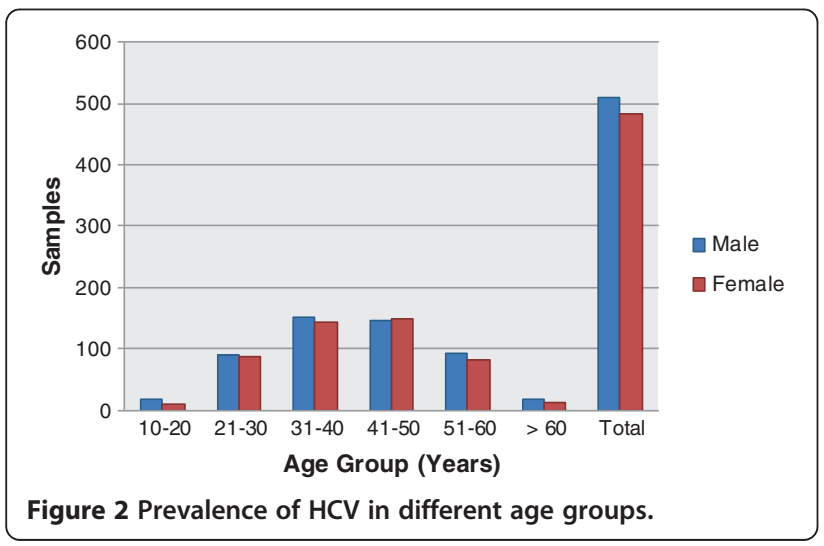

samples belonged to Sargodha were 60(6.03\%). Among these, $2(3.33 \%)$ were $1 \mathrm{a}, 1(1.66 \%)$ was $1 \mathrm{~b}, 1(1.66 \%)$ was $2 \mathrm{a}$, $46(76.66 \%)$ were $3 \mathrm{a}, 3(5 \%)$ were mixed and $7(11.66 \%)$ were untypeable genotypes. Total HCV samples belonged to Mandi Baha ud Din were 135(13.56\%). Among these, 5 $(3.70 \%)$ were $1 \mathrm{a}, 1(0.74 \%)$ was $1 \mathrm{~b}, 119(88.14 \%)$ were $3 \mathrm{a}$ and $4(2.96 \%)$ were mixed gentoypes. Six $6(4.44 \%)$ were untypeable genotypes. The Genotyped samples that belonged to Jhang were 86(8.64\%). Among these, 2(2.32\%) were $1 \mathrm{a}, 1(1.16 \%)$ were $1 \mathrm{~b}, 1(1.16 \%)$ were $2 \mathrm{a}, 76(88.37 \%)$ were $3 \mathrm{a}, 1(1.16 \%)$ was $3 \mathrm{~b}, 2(2.32 \%)$ were mixed genotypes and $3(3.48 \%)$ were untypeable genotypes (Table 1 ).

\section{Discussion}

In this study, we demonstrated the HCV genotype distribution in different categories and the existence of association between genotypes and gender. The current study evidently depicts that there is no significant difference between gender and HCV genotypes because HCV genotypes were distributed with equal probability between the both sexes. These results are in accordance with many preceding studies showing no statistical difference in gender with respect to variation among genotypes in Pakistan [11-13]. Current study contradicts with a Libyan study in which HCV genotype 1 possessed significant association with males whereas genotype 4 showed high frequency in females [14]. The results of this study have shown that high prevalence of $\mathrm{HCV}$ infection was found at age of $<50$ years. These findings are in partial agreement with the former studies $[10,11,15]$ that noted the high prevalence in age group of $\leq 40$ years $[13,16]$.

It has been observed that HCV genotype $3 \mathrm{a}$ is highly prevalent in Pakistan [10-13,15-17], in contrast, a study has revealed the results from Balochistan where the 1a has higher frequency [7]. Current study revealed that genotype 3a is most frequent and common followed by genotype 1a in $\mathrm{HCV}$ infected patients. The HCV genotype distribution pattern is similar to the reported studies from neighbouring 
South Asian countries where genotype 3 is more frequent than others [16]. Current study has also detected a rare genotype $5 \mathrm{a}$, which is less reported and less frequent. This finding is in agreement with the previous studies that showed the presence of $5 \mathrm{a}$ but rare status of this genotype $[7,12,15]$. These findings are in contradiction with some studies that have shown the partial absent status of genotypes 4, 5, 6 [10].

In this study, we have determined the viral load with respect to genotypes in different districts and gender as showed in Table 2. On the basis of specified levels, we categorized viral load into three classes i.e. low level $(<60,0000 \mathrm{IU} / \mathrm{ml})$, intermediate level $(60,0000$ $80,0000 \mathrm{IU} / \mathrm{ml})$ and high level $(>80,0000 \mathrm{IU} / \mathrm{ml})$. The results of our study are in line with previous findings that there are no significant differences in HCV RNA levels of both genders (Table 2) [18]. We have observed that the viral load in $29 \%$ patients was less than $600,000 \mathrm{IU} / \mathrm{mL}$, while it was between $600,000-800,000 \mathrm{IU} /$ $\mathrm{mL}$ in $27.83 \%$ patients and $25.22 \%$ patients had more than $800,000 \mathrm{IU} / \mathrm{mL}$ viral load. It is already established that under therapeutic considerations sustained virological response (SVR) can be easily attained in genotype $3 \mathrm{HCV}$ patients with low viral load $(<600,000-800,000 \mathrm{IU} / \mathrm{ml})$ when compared with patients having high viral load (>600000-800000 IU/mL) [19,20]. HCV patients considered potential candidates for Interferon (IFN) therapy. But most of people in Pakistan deprived of this therapy because of high cost, little awareness among common people and lack of genotyping information in many geographical regions. Limited data regarding treatment of $\mathrm{HCV}$ is available in Pakistan and no documented evidence has been found on the percentage of patient treated with IFN. So, based on this study a well-planned treatment protocol can be conducted and record of IFN treatment therapy can be carried out.

\section{Conclusion}

Current findings conclude that multiple genotypes of $\mathrm{HCV}$ exist in Pakistan in which $3 \mathrm{a}$ and $1 \mathrm{a}$ are more common. A better understanding of the impact of high HCV RNA levels during the progression of HCV infection is needed, in order to find patients who would get the most benefits from treatment against $\mathrm{HCV}$.

\section{Competing interests}

The authors declare that they have no competing interests.

\section{Author's contributions}

SQA, MNZ and TY designed and supervised research. SQA, MMA, FA, IQA,

SQA collected the samples and performed experiments. MMA, FA and MNZ analysed the data. SQA, FA, and MMA drafted the manuscript and all authors read and approved the final manuscript.

\section{Acknowledgements}

We wish to thank Muhammad Imran (Institute of biochemistry and

Biotechnology, UVAS, Lahore, Pakistan) for his intellectual support during revision of the article. Higher Education Commission of Pakistan funded the work.

\section{Author details}

${ }^{1}$ Quality Operations Laboratory, UVAS, Lahore 54000, Pakistan. ${ }^{2}$ Institute of biochemistry and Biotechnology, UVAS, Lahore 54000, Pakistan. ${ }^{3}$ Department of Epidemiology and Public Health, UVAS, Lahore 54000, Pakistan. ${ }^{4}$ Ideal Laboratories, Lahore 54000, Pakistan.

Received: 18 October 2013 Accepted: 7 February 2014

Published: 10 February 2014

\section{References}

1. Robertson B, Myers G, Howard C, Brettin T, Bukh J, Gaschen B, Gojobori T, Maertens G, Mizokami M, Nainan O, et al: Classification, nomenclature, and database development for hepatitis $\mathrm{C}$ virus $(\mathrm{HCV})$ and related viruses: proposals for standardization, International Committee on Virus Taxonomy. Arch Virol 1998, 143:2493-2503.

2. Tsukiyama-Kohara K, lisuka N, Kohara M, Nomoto A: Internal ribosome entry site within hepatitis C virus RNA. J Virol 1992, 66:1476-1483.

3. Hnatyszyn $\mathrm{HJ}$ : Chronic hepatitis $\mathrm{C}$ and genotyping: the clinical significance of determining HCV genotypes. Antivir Ther 2005, 10:1-11.

4. Simmonds P: Variability of hepatitis C virus. Hepatology 1995, 21:570-583.

5. Hoofnagle JH: Course and outcome of hepatitis C. Hepatology 2002, 36:S21-S29.

6. Jimenez-Mendez R, Uribe-Salas F, Lopez-Guillen P, Cisneros-Garza L, Castaneda-Hernandez G: Distribution of HCV genotypes and HCV RNA viral load in different regions of Mexico. Ann Hepatol 2010, 9:33-39.

7. Idrees $M$, Riazuddin S: Frequency distribution of hepatitis $C$ virus genotypes in different geographical regions of Pakistan and their possible routes of transmission. BMC Infect Dis 2008, 8:69.

8. Verbeeck J, Maes P, Lemey P, Pybus OG, Wollants E, Song E, Nevens F, Fevery J, Delport W, Van der Merwe S, Van Ranst M: Investigating the origin and spread of hepatitis C virus genotype 5a. J Virol 2006, 80:4220-4226.

9. Pawlotsky JM: Hepatitis C virus genetic variability: pathogenic and clinical implication. Clin Liver Dis 2003, 7:45-66.

10. Ali A, Nisar M, Ahmad H, Saif N, Idrees M, Bajwa MA: Determination of HCV genotypes and viral loads in chronic HCV infected patients of Hazara Pakistan. Virol J 2011, 8:466.

11. Afridi SQ, Zahid MN, Shabbir MZ, Hussain Z, Mukhtar N, Tipu MY, Akhtar F, Yaqub T: Prevalence of HCV genotypes in district Mardan. Virol J 2013, 10:90.

12. Attaullah $\mathrm{S}$, Khan $\mathrm{S}$, Ali I: Hepatitis C virus genotypes in Pakistan: a systemic review. Virol J 2011, 8:433.

13. Raja NS, Janjua KA: Epidemiology of hepatitis $C$ virus infection in Pakistan. J Microbiol Immunol Infect 2008, 41:4-8.

14. Elasifer HA, Agnnyia YM, Al-Alagi BA, Daw MA: Epidemiological manifestations of hepatitis $C$ virus genotypes and its association with potential risk factors among Libyan patients. Virol J 2010, 7:317.

15. Ahmad W, ljaz B, Javed FT, Jahan S, Shahid I, Khan FM, Hassan S: HCV genotype distribution and possible transmission risks in Lahore, Pakistan. World J Gastroenterol 2010, 16:4321-4328.

16. Sy T, Jamal MM: Epidemiology of hepatitis $\mathrm{C}$ virus (HCV) infection. Int J Med Sci 2006, 3:41-46.

17. Mujeeb SA: HCV 3 in Pakistan: does it offer more hope for cure and control. J Pak Med Assoc 2002, 52:191.

18. Schijman A, Colina R, Mukomolov S, Kalinina O, García L, Broor S, Bhupatiraju A, Karayiannis K, Khan B, Mogdasy C, Cristina J: Comparison of hepatitis $C$ viral loads in patients with or without coinfection with different genotypes. Clin Diagn Lab Immunol 2004, 11:433-435.

19. Dalgard O, Bjoro K, Hellum KB, Myrvang B, Ritland S, Skaug K, Raknerud N, Bell H: Treatment with pegylated interferon and ribavarin in HCV infection with genotype 2 or 3 for 14 weeks: a pilot study. Hepatology 2004, 40:1260-1265.

20. von Wagner M, Huber M, Berg T, Hinrichsen H, Rasenack J, Heintges T, Bergk A, Bernsmeier C, Haussinger D, Herrmann E, Zeuzem S: Peginterferonalpha-2a (40KD) and ribavirin for 16 or 24 weeks in patients with genotype 2 or 3 chronic hepatitis C. Gastroenterology 2005, 129:522-527.

doi:10.1186/1743-422X-11-24

Cite this article as: Afridi et al: Molecular epidemiology and viral load of HCV in different regions of Punjab, Pakistan. Virology Journal 2014 11:24. 